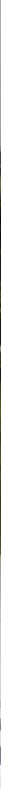

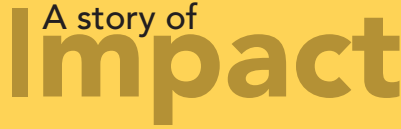

\section{NIOSH-funded Program Partners with Chiefs of Police to Reduce Traumatic Injuries Among New Jersey School Crossing Guards}

School crossing guards play an important role in the safety of children in route to school, yet these workers are at risk for traumatic injuries. From 1993-2008, 120 crossing guards died on the job in the U.S. ${ }^{1}$ In the same period, the New Jersey Fatality Assessment \& Control Evaluation (NJ FACE) program in the New Jersey Department of Health and Senior Services (NJDHSs) identified 14 NJ school crossing guard fatalities. ${ }^{2}$ All 14 incidents involved local government employees struck by motor vehicles. Additionally, the number of nonfatal occupational injuries and illnesses involving days away from work for NJ crossing guards totaled 892, $14 \%$ of which were motor vehicle-related. ${ }^{3}$ The majority of the nonfatal injuries were slips, trips, and falls resulting in sprains, strains, and fractures.

After NJ FACE-funded by the National Institute for Occupational Safety and Health (NIOSH) - investigated a fatality of a school crossing guard, a statewide occupational health surveillance intervention project was initiated to prevent motor vehicle-related injuries and raise awareness of the
- Crossing guard assists students in crossing a busy intersection. Photo by Arlington County, downloaded from flickr.

Relevant Information

In a crosswalk, crossing guards and students are equally vulnerable.

From 1993 to 2006, median days away from work for $\mathrm{NJ}$ school crossing guards almost always exceeded that for all local government occupations combined. ${ }^{6}$

In NJ, about 5,390 crossing guards were employed in 2010; that is the $4^{\text {th }}$ highest number in the nation. ${ }^{7}$

Proper training and personal protective equipment for crossing guards could reduce traumatic injuries.

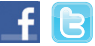

Follow NIOSH on Facebook and Twitter Sign up for eNews at cdc.gov/niosh/enews 
occupation's hazards. ${ }^{4}$ NJ school crossing guards are employed and trained by the municipality's police department; hence, a key partner was the NJ Association of Chiefs of Police. Other stakeholders included the NJ State League of Municipalities, the NJ State Safety Council, the No Safe Routes to School Coalition, the NJdHss Public Employees Occupational Safety and Health Program, and the No Municipal Excess Liability, a governmental risk-management organization with interest in crossing guard safety. NJ FACE developed a hazard alert titled Crossing Guards - Be Seen, Be Safe which included local and national injury data, job and safety training requirements, recommended and required personal protective equipment ( $\mathrm{PPE}$ ), safe work practice recommendations, and a compelling case study. ${ }^{5}$ All partners reviewed and endorsed the alert. An educational packet was mailed to all $534 \mathrm{NJ}$ police departments with the alert and a survey designed to collect surveillance data and solicit feedback.

\section{Impact}

Police chiefs who responded (224/534) to the survey were receptive to recommendations in the alert. ${ }^{6}$ The survey showed that slips, trips, and falls contributed to $50 \%$ of the injuries, motor vehicles contributed $40 \%$, and other injuries including sprains, strains, and dog bites contributed $10 \%$. Not all police departments provided PPE required by law. NJ FACE received requests for over 1,300 additional copies of the alert to distribute to crossing guards.

A follow-up mailing of the alert was sent to the same 534 police departments one year after the initial mailing. A follow-up survey was also included, in which police chiefs were asked to report all injuries and provide information on changes made since the initial mailing with regards to crossing guard safety training, PPE, and hazard awareness. The police chiefs who responded to the follow-up survey (303/534) reported adding or improving the following PPE for school crossing guards: ANSI Class 2 safety vest $(20 \% ; 46 / 231)$; retroreflective gloves $(27 \% ; 35 / 128)$; whistle $(20 \% ; 25 / 124)$; and a distinctive uniform/badge $(17 \%$; 28/167). Although school crossing guards throughout the U.S. continue to be at risk for injuries, collaborating with police chiefs to provide crossing guards with proper training, work practices, and PPE has shown great promise in reducing fatal and nonfatal injuries.

\footnotetext{
For more information, visit the NJDHSS Adult School Crossing Guards Web site at http://nj.gov/health/surv/crossing_guards.shtml or the NIOSH FACE Program site at www.cdc.gov/niosh/face.

${ }^{1-7}$ For a complete list of references, see www.cdc.gov/niosh/docs/2011-193/.
}

\section{SAFER • HEALTHIER - PEOPLE ${ }^{\text {TM }}$}

U.S. Department of Health and Human Services

Centers for Disease Control and Prevention

National Institute for Occupational Safety and Health

To receive NIOSH documents or more information about occupational safety and health topics, please contact NIOSH. Telephone: 1-800-cdc-info (1-800-232-4636) | TTY: 1-888-232-6348 | email: cdcinfo@cdc.gov | www.cdc.gov/niosh For a monthly update on news at NIOSH, subscribe to NIOSH eNews by visiting www.cdc.gov/niosh/eNews. DHHS (NIOSH) Publication No. 2011-193
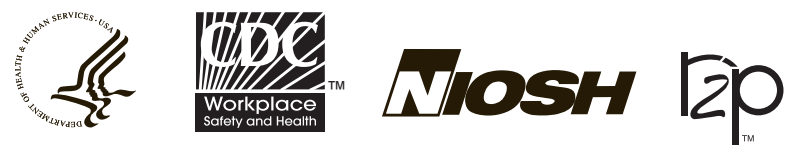